\title{
A Survey of Teacher Trainees' Expectations, Experiences and Assessment in Uganda
}

\author{
Alice Merab Kagoda
}

\author{
Nicholas Itaaga
}

School of Education, Makerere University, Kampala-Uganda.

\section{Doi:10.5901/jesr.2013.v3n5p43}

\begin{abstract}
112 Teacher Trainees participated in this study. The purpose of the study was to identify and explain teacher trainee's perceptions, experiences and their assessment of the teacher education programme in the school of Education. The objectives of the study included; To assess the teacher trainees' expectations when joining the School of Education. Identify the teacher trainee's experiences at the School of Education as they undergo the programme. To solicit the views of the teacher trainees on how to improve the teacher education programme. A qualitative approach was used to collect data using open ended questionnaires and focus group discussions. Results show that Teacher trainees do not receive adequate and appropriate career guidance at secondary school level. The School of Education does not effectively explain to them what is involved in the programme. Teacher trainees feel they are not adequately prepared to meet the demands and needs of secondary school curriculum. Recommendations include lecturers attending/oriented to a course of teacher education, more government funding and revision of teacher education curriculum
\end{abstract}

Keywords:Teacher Education, Teacher trainees' expectations/experiences, Evaluation

\section{Introduction}

Teachers play a pivotal role in any education system. They directly interface with the students during curriculum implementation and yet society will judge the performance of the entire education system from the performance of the graduates of the system. In society in general, teachers provide leadership, useful in explaining government policies and documents written in foreign and technical language. Teachers are also at times leaders of social movements like environmental activities, formal and non formal education (Kagoda 2011). Teachers train the human capital essential for the development of a country and this is especially important in developing countries like Uganda. In light of the above roles of teachers in society it is important to evaluate the kind of education teacher trainees receive in teacher training colleges through their own voices.

Teacher education refers to the policies and procedures designed to equip prospective teachers with the knowledge, attitudes, behaviors, and skills they require to perform their tasks effectively in the classroom, school, and wider community. According to Talbert-J ohnson (2006) teacher education is so far the most important and known way of preparing change agents because success in educational reforms depends on the teachers' awareness of new changes, their attitudes 
to it and incorporation of the reforms in the daily conversation, professional values and commitment and knowledge of content. According to Allen (2009) teacher education programme refers to a prescribed set of studies, experiences, skills, and attitudes passed on to a teacher trainee, regardless of whether this is done pre-service or in-service, in preparing them for their future roles. Similarly Siddiqui (2009) argues that a teacher education curriculum framework needs to be in consonance with the curriculum framework for schools education, and a teacher needs to be prepared in relation to the needs and demands arising in the school context. Teacher education has to change from time to time responding to the broader, social, economic and political changes taking place in society. The needs include; engagement with questions of the learner, the learning process and the content and pedagogy of educating a teacher. Siddiqui (2009) continues to argue that teacher education may be seen as a reflective undertaking that is a meta-activity in nature which should show how things are done at school level, classroom level, basic theory and principles behind practices. This calls for skills and understanding of a different kind in addition to the skills required for actual school teaching. Androgogy (principles of adult learning) is the most appropriate pedagogy for teacher preparation. The weakest aspect of teacher education at the School of education Makerere University is the absence of professional preparation of teacher educators.

According to Elliot (1993) teachers learn how teach from experience and reflection. Teachers also learn through practice, acquiring knowledge and reflecting on their experience (Stuart et.al, 2009; Korthagen et.al 2006; Tailor et.al 1997). Learning to teach is a matter of learning the technical skills which enable individuals to function effectively in an education system. It requires knowledge and understanding of the subject. Learning about teaching is also enhanced through teacher trainees doing research on their own practice (Kagoda 2011). Ozgun-Koca et.al (2006) and Tailor (1997) emphasize the importance of the constructivist theory of learning in the training of teachers. They argue that it is learner centered environment in which past experience of the preservice teacher is respected. The learners construct their own knowledge by anchoring new information to pre-existing knowledge. Stuart et.al (2009) further states that some of this knowledge comes from formal training courses, the schools and from a wider social and cultural context in which they live. This construction of knowledge is interactive, inductive and collaborative. The teacher educator acts as a facilitator, provides pre-service teachers with a variety of experiences from which learning is built. The process maximizes social interactions between the learners so that they can negotiate meaning to what is exposed to them. In constructivist teacher education programmes there is less emphasis on skills and more on personal knowledge and on thinking skills. Constructivist teaching methods include role plays, debates, reflective journal writing etc. which a most effective in influencing behavior change (Mugimu 2009)

\section{Theoretic framework}

The researchers used the "An Chomhairle Mhuinteoireachta Teaching Council document; Initial Teacher Education Criteria and Guidelines for Programme Provider (2011) and National council for Teacher Education. New Delhi; National Curriculum Framework for Teacher Education (2009) as a guide to analyze students' responses and critique the programme at the School of Education. The following are the suggestion deemed relevant to this study;

- Make reflective practice the central aim of teacher education in areas of content and pedagogy which are constantly changing

- Teacher education should be open, flexible and not prescriptive and should put emphasis on the changing contexts and empower teacher trainees to relate her/him to them.

- The programme should equip teacher trainees with a set of competences to facilitate quality learning and cater for national priorities such as literacy, numeracy and inclusion. Ensure that the teacher trainees' own literacy and numeracy and competences in promoting and assessing literacy and numeracy, as appropriate to their curricular/subject area. 
- Modern teacher education functions under the canvas created by the master concepts of learning society, learning to learn, inclusive education, education for sustainable development, gender, promotion of the values of peace based on equal respect of self and others as well as respect for work. This implies making teacher education liberal, humanistic and responsive to demands of society.

- The worth and potential of indigenous culture as a source of rejuvenating teaching and learning. Multicultural education and culture specific pedagogy is the current trend.

- Acknowledge the existence of a diversity of learning spaces and curriculum sites such as the farm, work place, home, community, media etc apart from the classroom.

- Appreciation of the diversity of learning styles and contexts in which teachers have to function;- oversized classes, language, ethnic diversities, disadvantaged children etc.

- Teachers to be trained in organizing learner-centered activity based, participatory learning experiences like play, projects, discussions, dialogue, observation, visits, integrating academic learning with productive work.

- The programme should help them understand the psychosocial attributes and needs of learners, their special abilities and characteristics, their preferred mode of cognition, motivation and learning resulting from home and community socialization.

- The programme should facilitate teacher trainees' personal development and their growth into their professional role, enabling them to become responsible, trustworthy, effective, reflective practitioners.

\section{The Teacher Training programme at the School of Education, Makerere University.}

Teacher education at the School of Education is as old as Makerere University itself. Having started as the University of East Africa, it became an autonomous university in 1970 and started awarding its own qualifications. The mission of the School of Education is to prepare competent teachers at all levels; to work in the education system at Nursery school level, Primary school level, Secondary school level, and Teacher education level as Teachers, lecturers, Administrators, Inspectors of schools and Curriculum Designers and Implementers.

The vision of the School of Education is to be a center of Educational excellence and leadership in professional education, research and services relevant to the community sustainable development.

The School of Education is one of Makerere University's largest schools with three departments namely: Department of Educational Foundations and Curriculum Studies; the Department of Humanities and Language Education; and the Department of Science, Technical, and Vocational Education. The School of Education offers the professional teacher education course units while content for the disciplines is offered in the school of Liberal and Performing Arts, College of Natural and Applied Sciences, The college of Humanities and Social Sciences and the College of Business and Management Studies. As a consequence of liberalization and privatization of education in Uganda, numbers of both day and evening students increased four times between 2000 and 2010. Today the number of teacher trainees both undergraduate and post graduates ranges from 3000 to 4500 which is problematic in terms space available for teaching, large classes and school practice management (Kagoda 2011)

The teacher education programme at the School of Education, Makerere University is structured in such a way that a teacher trainee must take two teaching subjects in addition to the foundation courses and methodology courses. At the end of the second and third year of study, students are subjected to school practice which is practical and hands on experience in a classroom in a school of one's choice. School practice is assessed and grades awarded. It is also important to note that almost all teacher trainers have not undergone any orientation/training in teacher education programme and use their experience they gained as students in secondary schools or as undergraduates at the University. 


\section{Statement of the Problem}

Training teacher trainees in large numbers by teacher educators who are inadequately trained and inexperienced in their job is a big problem in teacher preparation. The fact that the School of Education does not have a single teacher education model that it follows in achieving its mission and vision is another issue that affects the training of teachers. The school of Education borrows ideas from the reflective model, the technical model, the social interaction model and the coaching model to guide teacher preparation. There is therefore a problem of lack of a single model in teacher preparation at the School of Education, Makerere University. Today most Ugandans believe that teacher education is for candidates who fail to get admitted to more "difficult" courses and is regarded as simple by most people in society as well as other academicians etc. Given such a scenario, the researchers sought to assess the teacher trainees' expectations, experiences, and their assessment of the program at the School of Education.

\section{The purpose}

The main purpose of the study was to identify and explain the teacher trainee's expectations, experiences and areas they feel need to be adjusted to make teacher training more effective and lifelong learners.

\section{Objectives}

The study was guided by the following objectives:

1. To assess the teacher trainees expectations when they joined the school of education.

2. To assess the teacher trainees' experiences at the school of education as they undergo the program.

3. To solicit the views of the teacher trainees on how to improve the teacher education program at School of Education, Makerere University.

\section{Methodology}

The research was basically qualitative in nature although a quantitative method in form of questionnaire with open ended questions was used. Qualitative approach was preferred because the study sought teacher trainees' perceptions, feelings and attitudes about the teacher education program. A survey design was used because of the need to obtain basic data that could be used for further research. Research took place within the premises of the School of Education, College of Education and External Studies, Makerere University, in 2012. The researchers used qualitative approach using first a questionnaire on 112 undergraduates and later focus group discussions with 20 teacher trainees. Questionnaires provided data on teacher trainee's background like for reasons choice of education as their career, their departments, and their scores in pre-entry examinations to University and other information regarding their experiences in the academic and social experiences in the School of Education.

The focus group discussions provided real insight into teacher trainees' experiences, with the various subjects of study in the foundations and teaching subjects, their interactions with their subject lecturers and peers, the learning facilities and teaching materials. The focus groups also provided teacher trainees a platform to voice their concerns which can be considered when reviewing the teacher education programme at the School of Education.

Participants included teacher trainees in their first, second, and third year of study. The purpose of using teacher trainees from 1- $3^{\text {rd }}$ was to ascertain their choice of education as a career given the current situation in Uganda where graduate teachers are not readily employed by government. The male students were slightly more than the female teacher trainees, $72 / 60$. Third 
year students were $62,2^{\text {nd }}$ year 19 and first year 31 . The researchers used only this number 112 because more information would have made no difference in terms of the nature of responses. The majority were third years therefore they have an informed position about the programme of teacher education at the School of Education. Out of the 112 students that participated in the study, 73 (65\%) were taking humanities subjects like History, Geography, Divinity, Economics, and Languages like Germany, English Language, Kiswahili, Islam etc. The remaining 39 (35\%) were taking science subjects like Mathematics, Physics, Chemistry, Biology. These are the subjects that the teacher trainees are expected to teach when they complete their programme. Data was collected through interviews and focus group discussions with the students. The participants were randomly selected and interviewed by the researchers themselves. Data was also collected through a critical perusal and auditing of the relevant documents within the School of Education

\section{Data Presentations and Discussions}

The first objective was; to assess the teacher trainees' expectations when they joined the School of Education

Data collected on student choice of education as their career reveal that the majority of the teacher trainees $(43 \%)$ had education as their third or fourth choice; while only $4 \%$ of the respondents chose education as their first choice. This implies that teacher trainees at the School of Education are not purely interested in the programme; they decide to take it as a last resort since they didn't qualify for the course of their first choice. This is confirmed by their pre-university entry scores. The highest point one can score at $A^{\prime}$ Level is 25; while the lowest person who qualifies to join university with only two principles passes can have ( 5 points). The majority of the teacher trainees in this study scored less than 22 points at Advanced Certificate of Education Examinations. Records in the School of Education Registrars office confirm to this trend of the nature and quality of students admitted to study teacher education. This implies that the teaching profession does not attract the best brains, those who perform best prefer programs like Bachelor of Laws, Business Administration, Social Work and Social Administration, Human Medicine, Veterinary Medicine, Engineering and many others.

Teacher trainees resort to education as a career for various reasons. The majority of the teacher trainees were inspired by their parents; some wanted to get knowledge to start up their own schools; based their decision on the low tuition at the school of education. Those who gave the reasons like ease of getting a job, love for the profession, teachers earn more because they do part time teaching in several schools were the minority. These findings imply that teacher trainees at the school of education join the teaching profession NOT out of their love for the profession but to use it as a stepping stone to other careers. One wouldn't blame them since government and private schools do not have the capacity to absorb them in the available schools. Students have interesting reasons for not choosing education as profession; Students have no respect for teachers: they see them as people with one shoe, one shirt, and one trouser. Others added on; earn little pay yet they are overworked. The majority of the respondents gave reasons related to the teachers' low public image, poor housing, and the meager salaries, which render teachers unable to meet their essential needs. The above factors help to explain the kind of expectations they had towards the teacher education programme.

Respondents were asked to indicate their expectations when they joined the school of education as well as those regarding content, curriculum, teaching methods, and extracurricular activities.

The majority of the respondents $(20 \%)$ expected to broaden their knowledge, followed by $17 \%$ who expected the program to be complicated. $16 \%$ of the respondents never expected foundation courses, implying that they were actually not informed about the details of the teacher education programme. On the other hand, only $2 \%$ expected more content than what they were being given; and 3\% expected appropriate content; "Expected more content that is appropriate" 
what they meant here, from focus group discussion was content relevant to what they were going to teach. Uganda has a severe shortage of textbooks and reading materials that are affordable to the majority of students in both secondary schools and tertiary institutions. In secondary schools teaching and learning depends on notes written by teachers and handed to students and this explains the response from the teacher trainees, "Expected a lot of notes". The above were some of the general expectations of the teacher trainees.

As regards their expectations on content, the respondents answered as presented below:

Findings reveal that the majority of the students had/have high expectations out of the teacher education programme. $17 \%$ indicated that they expected to find computers for every student; $16 \%$ expected simple content while $14 \%$ expected content to be for secondary schools for which they were being prepared. On the other hand only $1 \%$ expected precise and concise content; $3 \%$ expected easy and enjoyable content and similarly the same percentage expected practical lessons in the science subjects. There are two kinds of contents for students of education; content of the two teaching subjects from other colleges and content in the school of education, foundation courses and teaching subjects. To some students this combined content of subject matter is too much since most people believe education is simple and anybody can pass it.

As regards teaching methods the students' expectations of teaching methods at university, findings reveal that the majority of the respondents (28\%) expected complex work not easy work as far as teaching methods are concerned. This was followed by those who expected lectures $(21 \%)$; and those who expected participatory methods not lectures alone (18\%). On the other hand, very few students ( $1 \%$ ) expected the use of notes, research methods and practical methods in the teacher education programme. Interestingly there are those who mentioned in the focus groups that they expected use of modern facilities in the school of Education; "we expected use of modern facilities ICT"The science teacher trainees were crying for practical methods; we expected to be guided in practical experiments. They added on, the lecturers provide the materials for experiments and expect us to do the work without their supervision and guidance. We were taught like that in secondary schools by our teachers, just as they were taught. This explains why science subjects are not performed well in secondary schools. This is hard to explain in this survey by the researchers.

Lastly the respondents were asked about their expectations regarding extracurricular activities at the School of Education. Their responses are indicated below:

Findings revealed that the majority of the respondents expected to find football as one of the extracurricular activities at the School of Education during their teacher training program. "Games like badminton, netball, basketball, football, volley ball and other sports like in the secondary schools" Others expected clubs "We lack clubs like debates. The teacher trainees' response in the focus groups was "In secondary schools we are expected to be games masters, patrons of clubs, and other responsibilities but we are not exposed to them in the School of Education, how you expect us carry out such activities when we graduate?"To the researchers, this is a very important gap identified in the teacher education program at the school of education.

The second objective of the study was to evaluate the teacher education programme by asking teacher trainees their experiences with the foundations and curriculum courses, the school practice and the teacher education program in general.

The teacher trainees have no problem with the foundation courses despite being new to them. They said in the focus groups that they are interesting and helped them during school practice. The only complaint was that although they enjoyed the content of the courses the examination questions were difficult. Regarding the methodology courses, ie teaching methods; they want more supervised experiments (Science) and teacher centered methods instead of the lectures only. The school practice responses are as indicated in the following tables: 
Table 1: Students' responses on the weaknesses of School practice exercise

\begin{tabular}{|l|l|}
\hline & Response \\
\hline & Some lecturers have poor dress code \\
\hline & Supervisors visit teacher trainees once and assess them on just one visit \\
\hline & Supervised by a group of lecturers/a variety of lecturers in a single lesson \\
\hline & Need adequate materials and constant supervision \\
\hline $\begin{array}{l}\text { Teaching practice should be done in all semesters especially in the nearby schools and } \\
\text { evaluated in a summative way }\end{array}$ \\
\hline \begin{tabular}{l} 
We get little content of subject matter \\
\hline
\end{tabular} Evaluation of School practice is subjective \\
\hline & Being at school from 8.00 to 5.00pm for five days \\
\hline & lecturers have no ideas about other subjects they supervise during teaching practice \\
\hline
\end{tabular}

Funding higher education is a big issue in developing countries like Uganda. Inadequate funding of school practice, the large numbers of teacher trainees and the small number of supervisors is the major cause of shortcomings mentioned by teacher trainees. Secondly supervisors are not exposed to pedagogy of teacher education to enable them do a good job. Thirdly the quality of students some of whom lack life skills for survival in certain contexts makes them complain over trivial issues such as Being at school from 8.00 to $5.00 \mathrm{pm}$ for five days" "TP is expensive, Teacher Trainees should be well facilitated". The general economic situation in the country is not very good explaining the responses of some teacher trainees.

Students were asked if they feel adequately prepared for the job of a teacher. Their responses are displayed in the table below:

Table 2: Students' responses on whether they have been adequately prepared as teachers

\begin{tabular}{|l|l|}
\hline & Response \\
\hline & $\begin{array}{l}\text { Not professionally prepared, I feel not well trained - no field trips yet these are } \\
\text { required when we graduate in secondary schools. }\end{array}$ \\
\hline $\begin{array}{l}\text { Not adequately trained: - methods used could not help me adequately in class at } \\
\text { secondary school }\end{array}$ \\
\hline & Conceptualize teaching, preparation for teaching not well handled \\
\hline & Not well trained, cannot relate what I studied to everyday life. \\
\hline $\begin{array}{l}\text { Use of ICT is not emphasized as a unit for us to have exposure yet some schools } \\
\text { have modern technological devices to instruction }\end{array}$ \\
\hline $\begin{array}{l}\text { Biology teacher trainees are less involved, in fact nothing at all in dissection } \\
\text { practical so they go out into the field ill prepared. }\end{array}$ \\
\hline $\begin{array}{l}\text { The Teacher Education programme is too compacted that is, it has many course } \\
\text { units. }\end{array}$ \\
\hline
\end{tabular}

Source: Field data

Respondents were asked to suggest practical ways of improving on the teacher education programme at the School of Education. Their responses are as indicated in the table below: 
Table 3: Responses on how to improve $t$ he teacher education programme at the School of Education

\begin{tabular}{|l|l|}
\hline & Response \\
\hline & Improve Teacher Education by removing weak lecturers \\
\hline & TE improve by strict supervision of School practice \\
\hline & Give feedback of coursework \\
\hline & $\begin{array}{l}\text { Concentrate on particular subjects not generalized subjects } \\
\text { especially in chemistry }\end{array}$ \\
\hline & Improve practical lessons in practical subjects \\
\hline & Teacher Education: Integrate theory with practice \\
\hline Carrying out more study trips and more practical exercises for science subjects \\
\hline Buy more computers because the available ones are few \\
\hline $\begin{array}{l}\text { Make the content in the teaching subjects related to what is taught in schools } \\
\text { and not for masters (Biology and Chemistry) }\end{array}$ \\
\hline $\begin{array}{l}\text { Train TT about other side ventures of how to earn more money because most } \\
\text { of us are currently dying of poverty. }\end{array}$ \\
\hline TE improve the teaching of mathematics with more practical time \\
\hline Admit high performers not failures in Teacher Education \\
\hline Improve on the interaction between students and lecturers \\
\hline Equip lecturers with modern methods of teaching \\
\hline Integrate gender in the course \\
\hline Lectures should get time and update their materials they give us in class \\
\hline Increase the teacher education program from 3 to 4years \\
\hline Reduce content covered \\
\hline More space for lectures - avoid going to dining halls \\
\hline
\end{tabular}

Source: Field data

The above responses to the teacher education programme and how it can be improved reveal the shortcomings and gaps which need to be filled by making reforms. In the area of content students feel the course is overloaded with content of the teaching subjects and that of professional courses. Some students do not understand why for example in the subject geography, they study courses like; population, settlement, urban, Research methods in Geography etc, while in secondary schools they are required to teach regional papers of Africa, East Africa, Uganda, North America, China, the Rhine lands, Physical Geography, problems of Development. Nobody has explained to them the importance of broadening their knowledge base; confirming Sidiqqui (2009) similar observation in Delhi, that the disciplinary knowledge is ignored as part of pedagogy. The Teaching Council of (2011) recommends that teacher trainees should have the opportunity to" reflect on the subject content knowledge, subject pedagogical knowledge, pedagogy, literacy and numeracy in general, especially as appropriate to the curriculum/syllabus" This would help the teacher trainees conceptualize the importance of having a broad knowledge base of the teaching subject. The teacher trainees are crying out that; concentrate on content relevant to what is taught in secondary schools not generalized subjects. Some have suggested reduction of subject content while others advocated extension of the training period from three to four years.

Lack of use of ICT in the training of teachers is another complaint since some secondary schools have already embraced this approach to teaching. The Teaching Council (2011) advocates "use .of ICT in teaching and learning; research and independent study, all of which are important components of teacher trainees' developing professional skills" (pp14) As mentioned before, inadequate funding of higher education has had adverse effect on teaching and learning in the university; the computers are very few compared to the large number of students, the lecturers 
themselves are computer illiterate and some of them lack personal computers etc. The university cannot even provide a computer in lecturers' offices to be shared by two or three in a room. Some well trained, competent lecturers have left the University for Green Pastures elsewhere leaving behind what teacher trainees have described as; not adequately trained: - methods used could not help me adequately in class at secondary school. We didn't conceptualize teaching, preparation for teaching not well handled. Not well trained, cannot relate what I studied to everyday life" The situation with science education is more alarming, the teacher trainees are crying for more practical sessions while humanities students for interactive methods of teaching; "Biology teacher trainees are less involved, in fact nothing at all in dissection practical so they go out into the field ill prepared" The students suggest that lecturers should update their notes every year, lecturers should be equipped with modern methods of teaching, and others recommend removal of weak lecturers from the school of education. This is not to defend and justify the lecturers' behavior and practices by the researchers, but the fact is the teaching materials are inadequately provided; fieldwork cannot be carried out because of inadequate funds, the meager salaries which necessitates moonlighting to make ends meet, makes them to appear less committed to their work. Lecturers have no time to interact with teacher trainees outside the lecture rooms because of the above reasons. Most important lecturers are not oriented to teacher education pedagogy contributing to weaknesses mentioned by the teacher trainees. The teaching Council (2011) recommends appropriate staff development policies to be put in place to ensure that staff update their qualifications and enhance /expand their knowledge and expertise as necessary.

On the other hand some students recognize the quality of fellow students which in one way or the other affect the teaching and learning, "Admit high performers not failures in Teacher Education" This is difficult since the policies on cut off points for admission in university allows such candidates. While the students recommended integration of gender, non mentioned inclusive education, education for sustainable development, values of peace, the concept of learning society and learning to learn as advocated by Siddiqui (2009)

\section{Conclusion}

It is clear from the teacher trainees' voices that they didn't receive any career guidance in their respective secondary schools especially the teacher education Course. This explains the kind of expectations they had as they joined the School of Education. Secondly the School Of Education has made little effort if any to explain to the students the components of Teacher Education and what it means to be a teacher when they are admitted in the course

Teacher trainees feel they are not adequately prepared to be teachers of secondary schools in Uganda. They mention the over packed program with many courses which are inadequately taught, lack of adequate teaching space at the School and instead use dining halls, inadequate teaching materials like textbooks, lecturers who do not seem to care for them and many other factors. The monotonous methods of teaching which exclude learner centered approaches like field work, debates, and experiments in science subjects. Extra-curricular activities are part and parcel of schools curricular but teacher trainees are not exposed to them at the School of Education.

Students suggest that teacher education at the school of Education should be more professionalized. They feel the teacher trainers are not adequately trained that is why they do not have modern methods of teaching. Teacher trainees want to reduce the number courses offered to education students or extend the training period from 3 to four years. They want to improve on the supervision of school practice which they feel is insufficiently done by some lecturers.

\section{Recommendations}

The School Of Education with the Academic Registrars' office should endeavor to do career guidance in secondary schools of Uganda 
Professional development for teacher educators should be promoted by the College of Education through research and other activities like attending conferences and workshops. The School of Education need also revise its curricular to meet the demands of teacher trainees.

The government of Uganda need to increase funding for teacher education to enable adequate supervision of school practice, buy enough teaching materials, provide enough teaching space, pay a living salary to lecturers and other needs that require financial assistance.

It is important to note that these are voices of teacher trainees, a study of the lecturers' opinion, feeling and attitudes toward the teacher education progamme.

\section{Acknowledgement}

The researchers would like to recognize the teacher trainees of academic year 2012/2013 for their invaluable contribution to this study.

\section{References}

Allen J.M (2009) Valuing practice over theory: How beginning teacers re-orient their practice in the transition from University to workplace. Teaching and Teacher educaghran and tion, 25: 647-654

Elliot J . (1993) Reconstructing Teacher Education. London Palmer Press

Kagoda, A.M (2011) Role Models and Life Histories of Teacher Trainees as tools for Effective Teacher Education: A Case of Geography Teacher trainees, school of Education, Makerere University, Uganda In Academic Research International Volume 1 Issue 3

Karthogen F.J . Loughran and Russel,T (2006). Developing Fundamental Principles for Teacher Education Programmes and Practices. Teaching and Teacher Education 22 1020-1044

Mugimu C. (2010) Developing and Using Education Resources to support Teacher Education in Africa. Excellence in Higher Education (2010) 31-45

Ozgan-Koca, Sen A.I (2006) The Belief and Perceptions of Pre-service Teachers enrolled in Subject area dominant Teacher Education Program about Effective Education. In Teaching and Teacher Education 22 946-960

Siddiqui.M.A. (Ed) (2009) National Curriculum Framework for Teacher Education (2009). New Delhi National Council for Teacher Education

Stuart J. Akyeampong and Groft A (2009) (eds). Key Issues in Teacher Education. A Source Book for Teacher Education In Developing Countries. Oxford Macmillan

Talbert-Johnson, C (2006) Preparing Qualified Teacher Candidates for Urban Schools the importance of Dispositions. In Education and Urban Society 39 (1)

Tailor P.C, Fraiser B.J and Fisher D.L (1997). Monitoring Constructivist Classroom Learning Environments. Perth Australia. Curtin University of Technology.

The Teaching Council (2011) Initial Teacher Education: Criteria and Guidelines for Programme Providers. Ireland. An Chomhairle Mhuinteoireachta 